\title{
Phenotypic plasticity at fine-grained spatial scales: the scorched mussel Perumytilus purpuratus growing on Patagonian rocky salt-marshes
}

\author{
Yamila Gonzalez Giorgis ${ }^{1}$, María Cruz Sueiro ${ }^{2}$, Federico Márquez ${ }^{1,3}$ \\ ${ }^{1}$ Universidad Nacional de la Patagonia San Juan Bosco (UNPSJB), Blvd. Brown 3100, Puerto Madryn, Argentina. \\ (YGG) E-mail: yamila.gonzalez.g@gmail.com. ORCID iD: https://orcid.org/0000-0002-6977-4114 \\ ${ }^{2}$ Centro para el Estudio de Sistemas Marinos (CESIMAR) - CONICET, Boulevard Brown 2915, U9120ACF Puerto \\ Madryn, Chubut, Argentina. \\ (MCS) E-mail: sueiro@ cenpat-conicet.gob.ar. ORCID iD: https://orcid.org/0000-0003-3203-4785 \\ ${ }^{3}$ Instituto de Biología de Organismos Marinos (IBIOMAR) - CONICET, Boulevard Brown 2915, U9120ACF Puerto \\ Madryn, Chubut, Argentina. \\ (FM) (Corresponding author) E-mail: fede@ cenpat-conicet.gob.ar. ORCID iD: https://orcid.org/0000-0002-1613-9627
}

\begin{abstract}
Summary: Understanding phenotypic plasticity of species at different spatial scales is vital in the current context of an increasing pace of environmental changes. Through this knowledge, it is possible to predict their potential to adapt and/or evolve in face of new environmental conditions such as climate change, and/or to understand their ecological range expansion. In Patagonian rocky salt-marshes, one of the most abundant invertebrate species is the scorched mussel Perumytilus purpuratus. In this system, this mussel can be found inhabiting both vegetated and non-vegetated patches, which differ in critical environmental conditions. We performed a field study evaluating whether mussels growing in vegetated patches differ in shell shape from those growing in adjacent non-vegetated patches. We sampled individuals from both patch types and assessed their shell shape and size using geometric morphometrics. The results showed that mussels from vegetated patches had shells that were more dorsoventrally expanded, anterodorsally restricted and globose in shape than those from non-vegetated patches, which showed the opposite traits resulting in a more elongated shell. The differences found could be driven by the different conditions of temperature, desiccation rate, wave action and population density to which mussels are exposed in each patch type. These results revealed the striking phenotypic plasticity of shell form of this native species at a fine-grained scale, which could be one of the explanations for its success in its ecological range expansion.
\end{abstract}

Keywords: little mussels; ecomorph; geometric morphometrics; shape variation; rocky intertidal; Patagonia.

Plasticidad fenotípica en una microescala geográfica: el mejillín, Perumytilus purpuratus, que habita en las marismas rocosas de la Patagonia

Resumen: Poder comprender la plasticidad fenotípica de las especies, a diferentes escalas espaciales, es fundamental en un contexto de crecientes cambios ambientales. A través de este conocimiento, es posible predecir su potencial para adaptarse y/o evolucionar frente a nuevas condiciones ambientales tales como el cambio climático, y/o entender el modo en el que se expanden o expandieron sus rangos ecológicos. En las marismas rocosas patagónicas, una de las especies de invertebrados marinos más abundantes es el mejillín Perumytilus purpuratus. En este sistema, se lo encuentra en parches vegetados y sin vegetación que difieren en condiciones ambientales críticas. Mediante un estudio a campo, evaluamos si los mejillines que crecen en parches vegetados difieren en la forma de la concha de aquéllos que crecen en parches adyacentes sin vegetación. Para ello, se colectaron individuos de ambos tipos de parches y se evaluó la forma y el tamaño de las valvas utilizando morfometría geométrica. Los resultados mostraron que los mejillines de parches con vegetación presentan conchas más expandidas dorsoventralmente, con restricción anterodorsal, generando una forma globosa en comparación con la de los individuos de parches sin vegetación. Las distintas formas encontradas podrían deberse a las diferentes condiciones de temperatura, desecación, acción de las olas y densidad poblacional a las que están expuestos los mejillines en cada tipo de parche. Estos resultados muestran la presencia de plasticidad fenotípica en la forma de las valvas de esta especie nativa a una microescala espacial, lo que explicaría el éxito de esta especie en su expansión hacia nuevos ambientes.

Palabras clave: mejillín; ecomorfo; morfometría geométrica; variaciones morfológicas; intermareales rocosos; Patagonia.

Citation/Como citar este artículo: Gonzalez Giorgis Y., Sueiro M.C., Márquez F. 2020. Phenotypic plasticity at finegrained spatial scales: The scorched mussel Perumytilus purpuratus growing on Patagonian rocky salt-marshes. Sci. Mar. 84(4): 393-401. https://doi.org/10.3989/scimar.05040.16A

Editor: M. Ramón.

Received: January 30, 2020. Accepted: June 19, 2020. Published: August 3, 2020.

Copyright: (c) 2020 CSIC. This is an open-access article distributed under the terms of the Creative Commons Attribution 4.0 International (CC BY 4.0) License. 


\section{INTRODUCTION}

Phenotypic plasticity is the ability for a single genotype to modify its phenotypic characteristics in response to biotic and abiotic environmental conditions (Scheiner 1993). Assessing and uncovering the underlying causes of species phenotypic plasticity has been one of the main challenges of developmental biology and evolutionary ecology (Piersma and van Gils 2011). How populations and species respond to modified environmental conditions is critical to their persistence both now and into the future (Fox et al. 2019). Thus, this kind of knowledge has become increasingly important, particularly in the current context of an increasing pace of environmental changes (Orr et al. 2005, Kroeker et al. 2013). Through the understanding of this species ability, it is possible to predict their potential to adapt and/or evolve in face of new environmental conditions, such as changing climate scenarios and/or ecological range expansion (Gao et al. 2018). Therefore, a central question regarding plasticity is how and which organismal traits will respond to environmental variation and which environmental variables will induce those responses (Schwenk et al. 2009). Further, since environmental variation operates at different spatial scales, it is important to assess organism responses to environmental variables at different spatial scales (i.e. fine-grained and coarse-grained) (Baythavong 2011). These approaches will help to have a more complete and accurate insight into how the environment influences species phenotypic plasticity.

The occurrence of phenotypic plasticity is widespread in a variety of taxa of marine animals (DeWitt and Scheiner 2004, Miner et al. 2005). Exposure to environmental variation has been demonstrated to induce differences in a wide range of traits, including behavioural, morphological, physiological, biochemical, chemical and life history-related traits (reviewed by Padilla and Savedo 2013). In the case of shellbearing invertebrates, morphological changes constitute a well-known example of plasticity being related to different environmental pressures such as predation (Addison 2009, Brönmark et al. 2011, Scherer et al. 2016), competition (Covich 2010, Peyer et al. 2016, Bourdeau et al. 2015), and those imposed by abiotic conditions (Melatunan et al. 2013, Márquez et al. 2018). Particularly, mussels are known to exhibit a high level of phenotypic plasticity in shell morphology (Soot-Ryen 1955, McDonald et al. 1991). For instance, fluctuating asymmetry was found in the shell shape of Mytilus platensis from intertidal individuals compared with subtidal ones, as a response to environmental stress (Trivellini et al. 2018). Telesca et al. (2018) found that salinity, temperature and food availability fluctuations affect spatial patterns of shell shape variations in M. edulis and M. trossulus, lower salinities increasing the shell elongation. The effect of food availability and population density on shell form has also been explored for $M$. edulis, which show narrow shells with reduced food concentrations in high-density experimental situations (Alunno-Bruscia et al. 2001). Other environmental stressors such as substratum and habitat type (Kirk et al. 2007, Márquez et al. 2017), wave movement (Steffani and Branch 2003), predation (Seed 1969, Beadman et al. 2003, Kirk et al. 2007) and population density (Seed 1968, Brown et al. 1976, Cubillo et al. 2012) have been shown to induce phenotypic changes in many mussels species. However, environmental influx on mussel shells is complex, since various interacting factors may result in a variety of shape patterns (Telesca et al. 2018). This high level of plasticity of mussels in addition to their ecological and economic importance has turned them into a model system for studying phenotypic plasticity.

The scorched mussel Perumytilus purpuratus (Lamarck, 1819) exhibits a wide distribution range, with the presence of two phylogenetic clades (Trovant et al. 2015) in both the Atlantic and Pacific oceans and it spans over Chile-Peru (the northern clade) and the Magellanic biogeographic provinces (the southern clade, Briggs and Bowen 2013). Trovant et al. (2015) hypothesized that the differentiation of the southern clade originated from budding-off from range-edge populations of the northern clade, which adapted to a colder thermal regime with gradual expansion along the coasts of Patagonia. A recent study along the Argentinean coasts revealed that the allometric trajectories of shell shape in $P$. purpuratus did not correlate with latitudinal patterns of environmental variables (Márquez et al. 2018). Thus, the authors hypothesized that the variation pattern of shell shape of this species could be an adaptation to a specific habitat condition at fine grained spatial scales which in turn allowed them to expand their geographical distribution (Márquez et al. 2018). Perumytilus purpuratus inhabiting the Argentinean Patagonian coast provides an interesting model system for testing that hypothesis. This mussel dominates in abundance and coverage rocky intertidal environments (Adami et al. 2013), such as rocky saltmarshes (Sueiro et al. 2012), where it forms conspicuous aggregations called scorched mussel beds. In the specific case of rocky salt-marshes, which are characterized by the presence of the austral cordgrass Spartina densiflora Brong. (Bortolus 2010, Sueiro et al. 2011), mussels can be observed growing on both vegetated and non-vegetated patches (Sueiro et al. 2011). However, while individuals from vegetated patches show lower densities and form higher multilayer beds, those growing on non-vegetated patches show higher densities and form lower layer beds (Sueiro 2012). Moreover, previous studies have shown that vegetated patches provide shelter from desiccation and wave erosion and reduce temperatures compared with nonvegetated adjacent patches (Sueiro et al. 2011).

In this context, this work aimed to assess whether the shell shape of the native bivalve $P$. purpuratus has phenotypic plasticity at a fine grained spatial scale. To achieve this goal, mussels were sampled from vegetated and non-vegetated patches, and their shell shape was compared. We predict that the shell shape of individuals from vegetated patches will differ from those of individuals inhabiting non-vegetated patches given the differences in biotic and abiotic conditions associated with the presence or absence of the plant. 


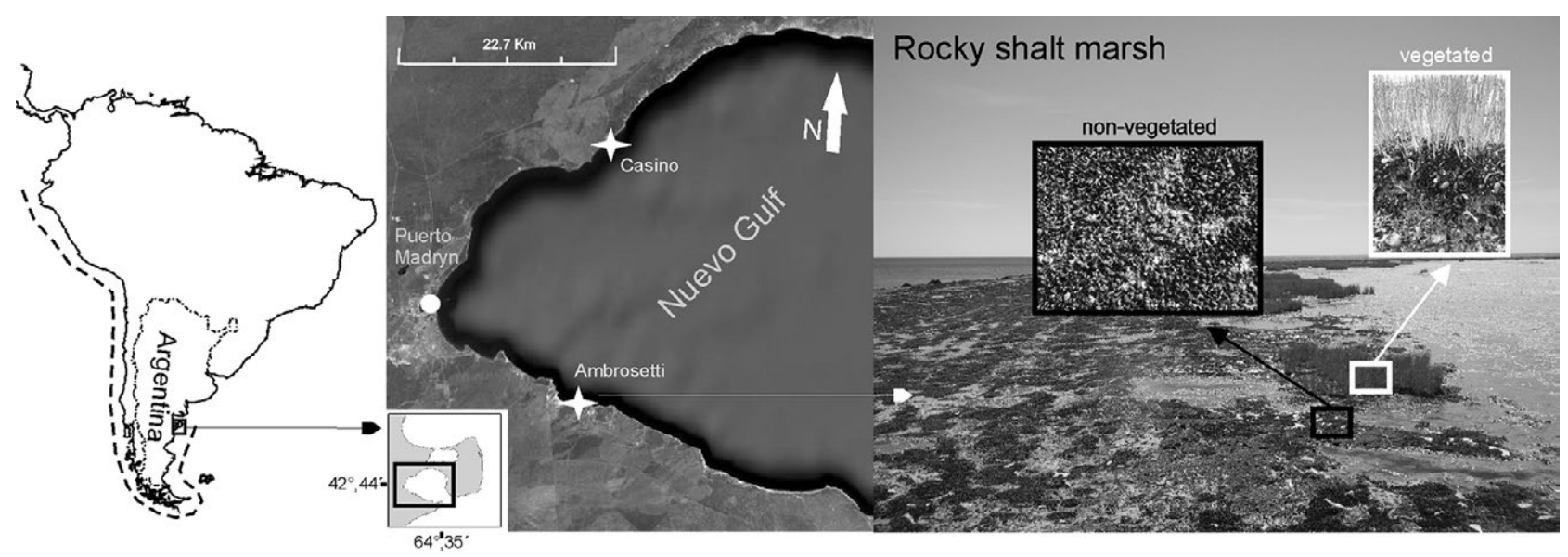

Fig. 1. - Map of the study area showing the distribution of the scorched mussel Perumytilus purpuratus (dashed line) and sampling sites (crosses). At the right, photographs showing a rocky salt-marsh and details of the sampled patches.

\section{MATERIALS AND METHODS}

Fieldwork was performed in two rocky saltmarshes with similar physiognomy located on Golfo Nuevo coasts (Chubut, Patagonia-Argentina): $\mathrm{Ca}-$ sino $\left(42^{\circ} 36^{\prime} \mathrm{S}, 64^{\circ} 50^{\prime} \mathrm{W}\right)$ and Ambrosetti $\left(42^{\circ} 50^{\prime} \mathrm{S}\right.$, $64^{\circ} 50^{\prime} \mathrm{W}$, Fig. 1). A total of 822 bivalves were sampled from vegetated and non-vegetated patches (Casino vegetated, $n=209$, non-vegetated, $n=217$; Ambrosetti vegetated, $n=194$, non-vegetated $n=202$; Fig. 1 ). The

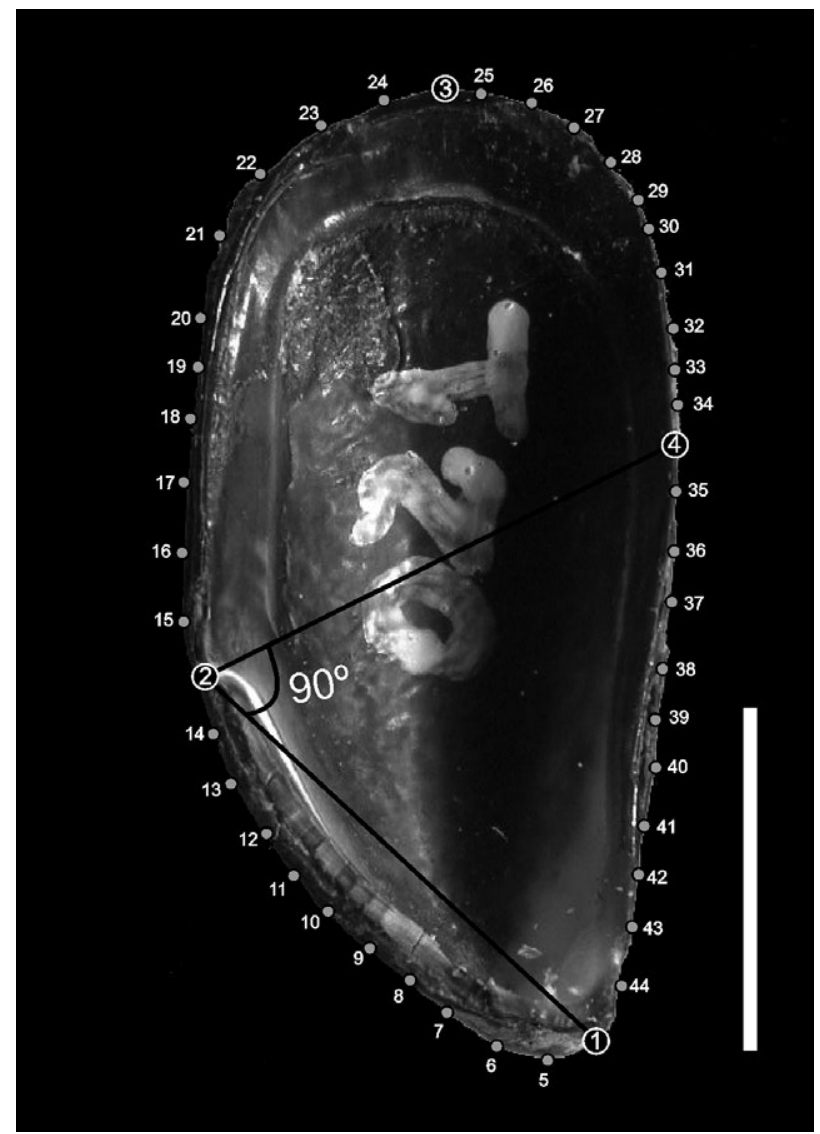

Fig. 2. - Landmark (black dots) and semi-landmark (grey dots) configuration to capture the outline shell shape of the scorched mussels Perumytilus purpuratus. Scale bar $=1 \mathrm{~cm}$. distances between those patches were no longer than one metre. The mussels were dissected and their shells carefully cleaned and dried. For analysis, only right shells were considered to avoid redundant information in symmetric structures. Each shell was oriented with its inner surface parallel to the plane of scanning and then digitized with an Epson Perfection v350 scanner with a 600 dpi resolution (Fig. 2).

\section{Geometric morphometrics data}

The landmark configurations on the images were digitized using a software series named TPS (Thin Plate Spline, Rohlf 2004). All individuals were digitized by one observer (YGG) using the module TpsDig2 (Rohlf 2016a). Landmarks are reference points that are homologous among individuals (Zelditch et al. 2004) and allow the shape of the structures under study to be captured. To capture contours between landmarks we used semi-landmarks, which are then homologated mathematically in an iterative process ("sliding") using the module TpsRelw (Rohlf 2016b) by means of an algorithm which minimizes the bending energy of the TPS function (Mitteroecker and Gunz 2009). We captured the shell shape using the following four landmarks: (1) umbo located on the anterior end; (2) the joint of the ligament with the dorsal contour; (3) the maximum posterior bend; and (4) the intersection of the dorsal contour at $90^{\circ}$ of the line formed between landmarks 1 and 2 . In addition, 40 semi-landmarks were used to determine the outlines along the shell. The 10 first semi-landmarks (5-14) were located between landmarks 1 and 2; the second 10 (25-34) between landmarks 3 and 4; and the last 10 (35-44) between landmarks 4 and 1 . The same landmark and semi-landmark configuration (Fig. 2) was used in $P$. purpuratus by Márquez et al. (2018).

With MorphoJ software, the dataset with coordinates of the aligned individuals was subdivided using classifiers as vegetated or non-vegetated rocky intertidal areas per site. The effects of rotation, translation and scale were eliminated by Procrustes analysis (Rohlf and Slice 1990). We used the Procrustes coordinates as shape variables to perform the multivariate statisti- 


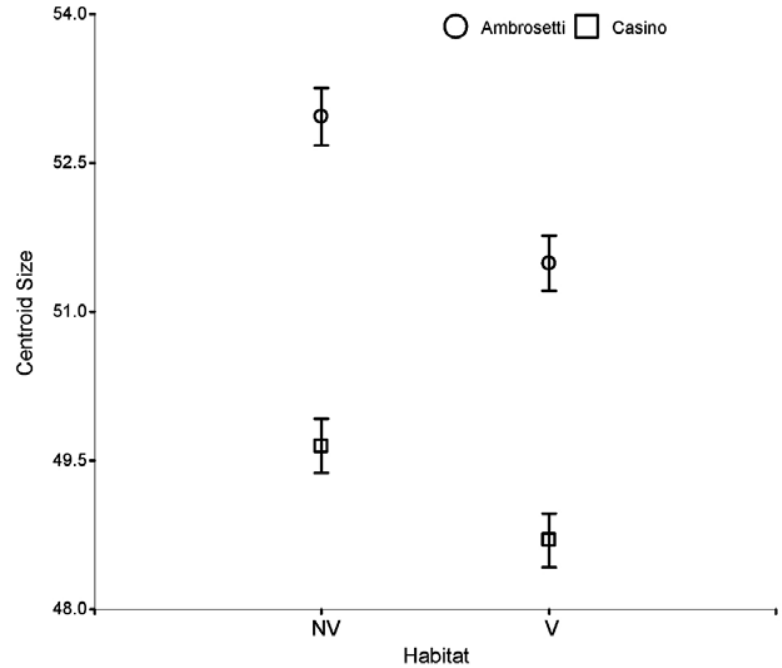

Fig. 3. - Mean and standard error of shell size (centroid size) of the scorched mussel Perumytilus purpuratus sampled from vegetated

(V) and non-vegetated (NV) patches in two rocky salt-marshes.

cal analyses (Klingenberg 2011). The centroid size of individuals, defined as the square root of the sum of the squared deviations of landmarks from the centroid (Bookstein 1991, Zelditch et al. 2004), was used as a proxy for shell size.

To evaluate and correct the putative allometric effect (change in the shape associated with size increment), a multivariate regression of shape on centroid size variables was performed (Bookstein 1991, Monteiro 1999) for each rocky salt-marsh. To evaluate the independence between the shape and size variables, we carried out a permutation test with 10000 rounds (Bookstein 1991, Zelditch et al. 2004). Centroid size was examined using a two-way analysis of variance that included the fixed effects of habitat (vegetated and non-vegetated) and site (Casino and Ambrosetti rocky salt-marshes) and any interaction between them. Centroid size and model residuals were examined for normality and homoscedasticity. Principal component analysis was carried out to arrange the individuals on maximum shape variation axes in order to be able to describe this variation. Finally, to find the shape components that maximize the separation between vegetated and non-vegetated patches, a discriminant analysis was performed, and the difference between means was tested by the $\mathrm{T}^{2}$ Hotteling test with 1000 permutations.

\section{RESULTS}

\section{Variation in shell size and shape}

The effects of habitat and site on centroid size were statistically significant, with mussels from nonvegetated patches showing higher values than those from vegetated patches $\left(\mathrm{F}_{(821,1)}=19.02, \mathrm{p} \leq 0.001\right)$ and mussels sampled from Ambrosetti showing higher centroid size than those from Casino rocky salt-marsh $\left(F_{(821,1)}=120.21, p \leq 0.001\right.$; Fig. 3$)$. The interaction term was not significant $(\mathrm{p}=0.35)$.
The presence of allometry in the individuals obtained from the two intertidal areas was proved $(p<0.0001$; Fig. 4). Therefore, the shell shape analyses were continued using the residuals of the multivariate regression. This eliminated the allometric component, which showed a $8.76 \%$ shape variation due to size change. The same allometric pattern was observed at the two sites; the smaller individuals had round shapes characterized by a longitudinal compression with a dorsal-ventral widening, while the bigger ones had slender shells with a longitudinal elongation and a dorsal-ventral compression (Fig. 4).

The allometric-free shell shape variations were summarized in a scatter plot for the first three principal component scores, which accounted for around $85 \%$ of the total variation; the other principal components were not taken into account because their contribution to variation was less than 5\% (Fig. 5) (Zelditch et al. 2004). Individuals from Casino and Ambrosetti showed the same variation pattern in morphospace (Fig. 5). Individuals at the positive extreme of PC1, which was associated with globose shape, had an expansion in the dorsal-ventral area, a ventral displace-

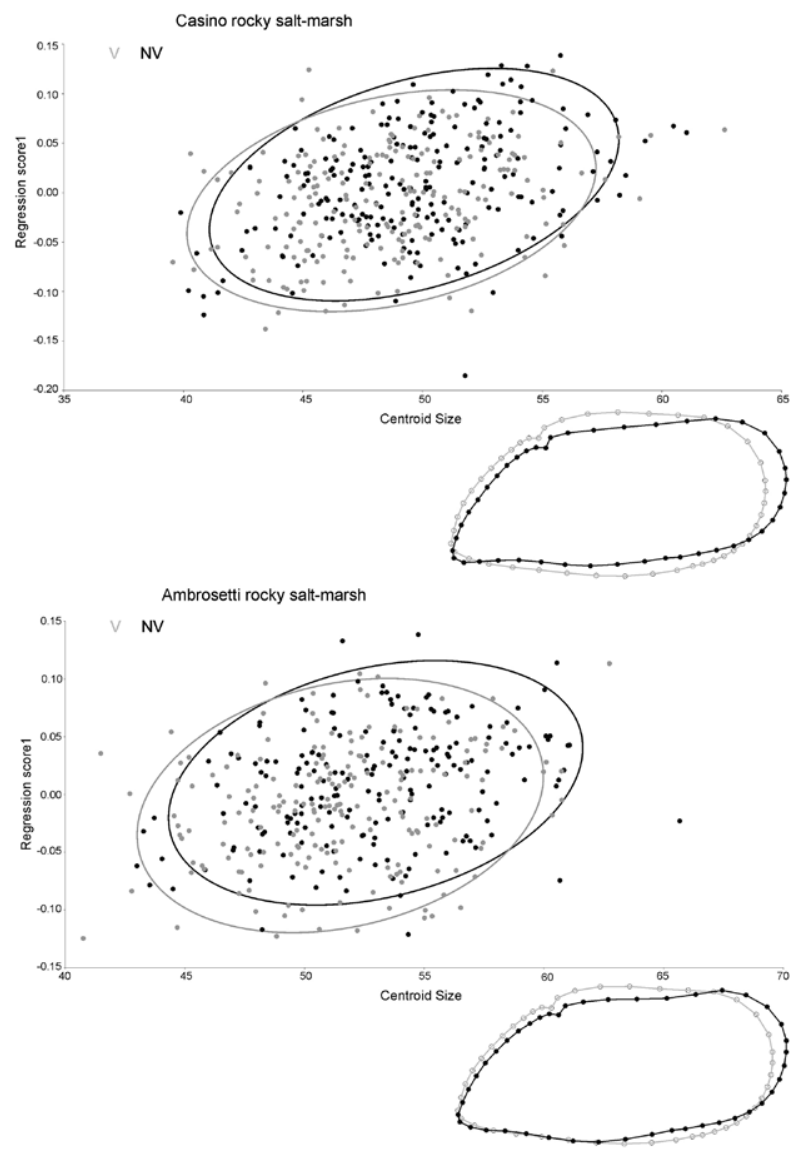

Fig. 4. - Regression of shell shape onto centroid size, illustrating allometric growth of shape of the scorched mussel Perumytilus purpuratus sampled from vegetated (V) and non-vegetated patches (NV) in the Casino and Ambrosetti rocky salt-marshes. The 95\% equal frequency ellipses are shown for vegetated (V) and non-vegetated (NV) patches and represent that each point has a probability of 0.95 of falling within the ellipse. The shell diagrams represent the shape change predicted from the average shape (grey wireframe) to an increment of 30 scale factor of centroid size (black wireframe). 
Casino rocky salt-marsh

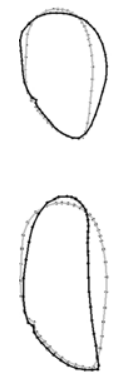

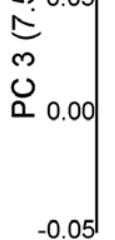
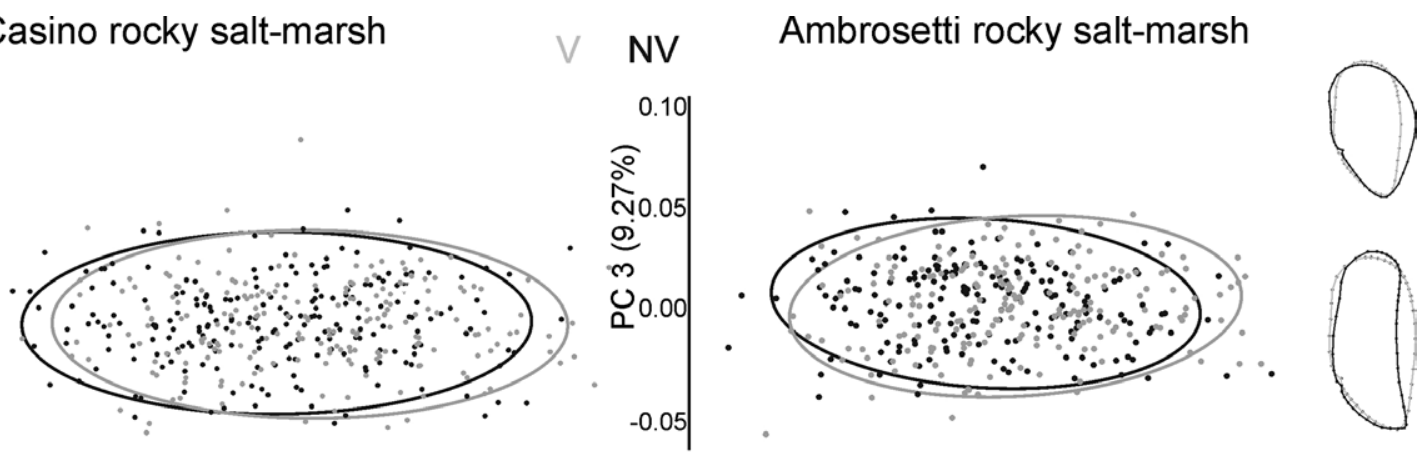

(
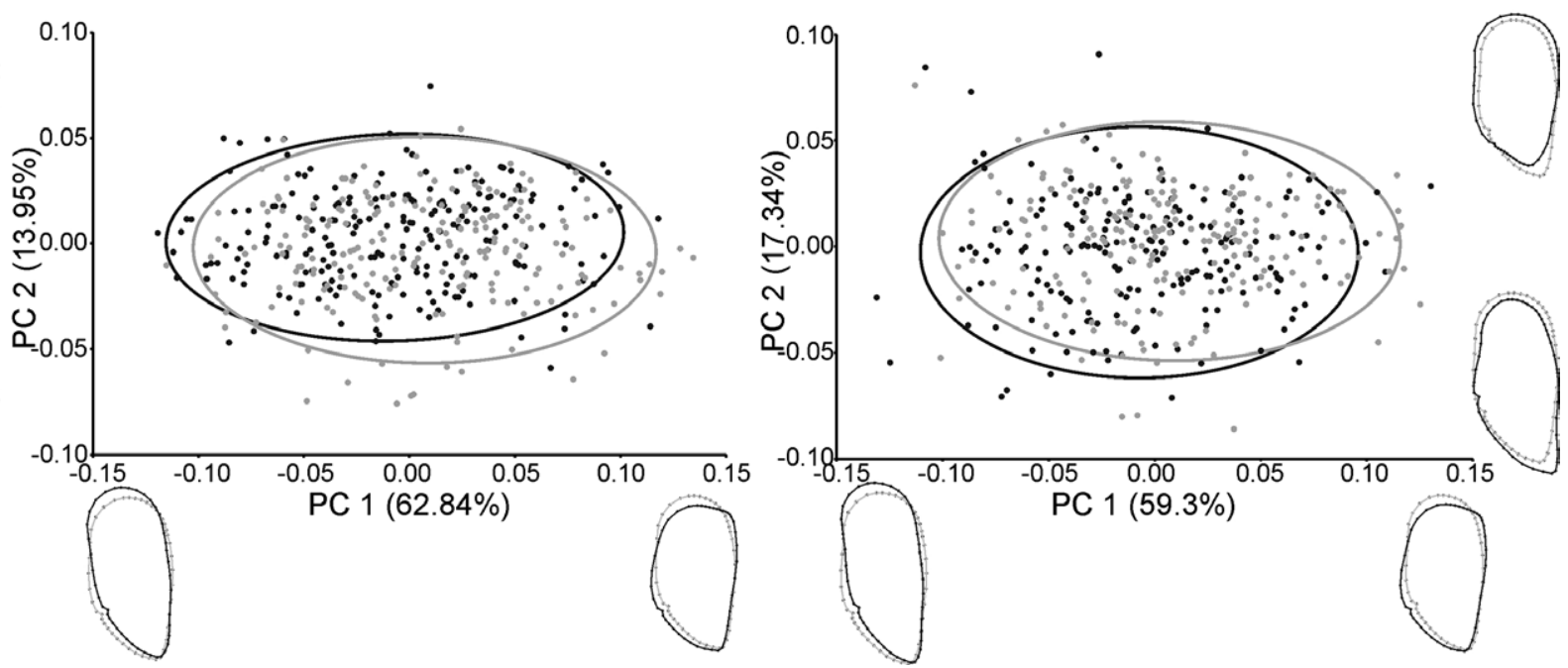

Fig. 5. - Principal component analysis of shell shape of the scorched mussel Perumytilus purpuratus sampled from vegetated (V) and nonvegetated (NV) patches in the Casino and Ambrosetti rocky salt-marshes. The percentages of variance explained by principal component axes (PC) are in parentheses. The 95\% equal frequency ellipses are shown for vegetated (V) and non-vegetated (NV) patches and represent that each point has a probability of 0.95 of falling within the ellipse. Polygon graphs represent the global mean shape (grey outlines) to the extreme shape (black outlines). This displacement is represented by a scale factor of 0.15 and -0.15 for the two locations equally.

\section{Casino rocky salt-marsh}
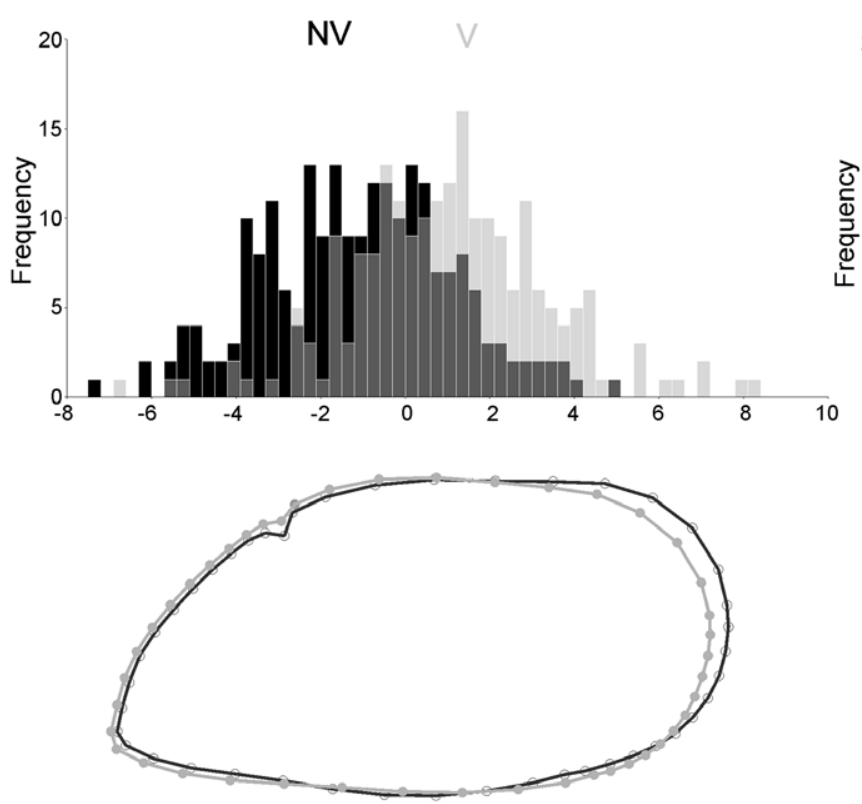

\section{Ambrosetti rocky salt-marsh}
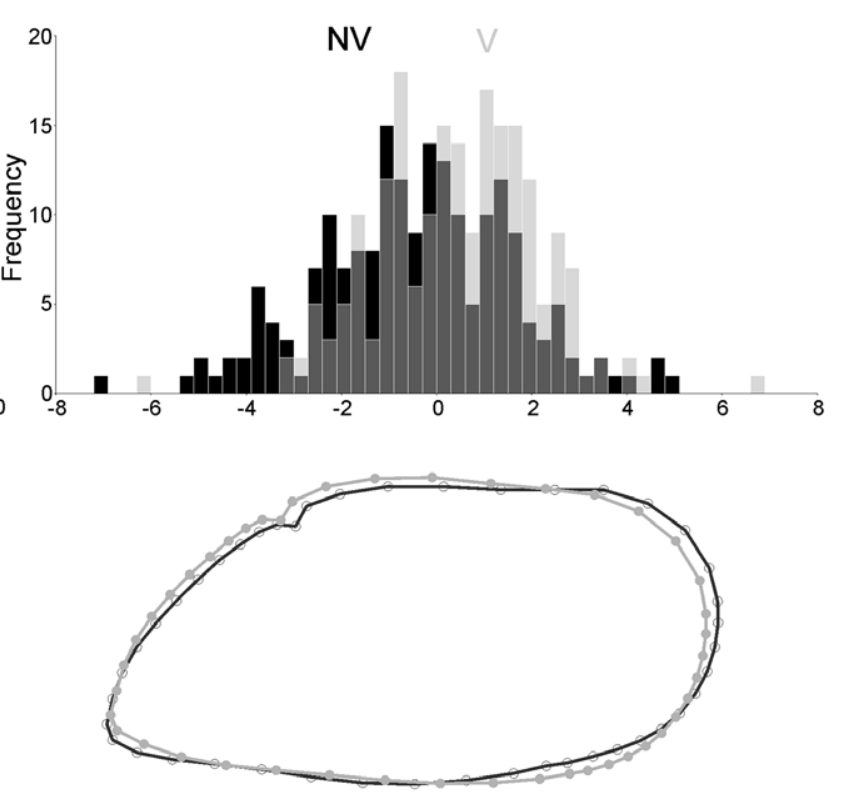

Fig. 6. - Discriminant analysis of shell shape of the scorched mussel Perumytilus purpuratus sampled from vegetated (V) and non-vegetated patches (NV) in the Casino and Ambrosetti rocky salt-marshes. The classification of discriminant frequencies predicted by the iterative crossclassification analysis between vegetated patches (grey bars) and non-vegetated patches (black bars) are shown. Strong grey bars show the overlap. For better visualization, the changes are exaggerated by a scale factor of 3 . 
Table 1. - Differences between means for shell shape of the scorched mussel Perumytilus purpuratus sampled from vegetated (V) and non-vegetated (NV) patches in Casino and Ambrosetti rocky salt-marshes.

\begin{tabular}{lccc}
\hline Site & Hotteling T & $\begin{array}{c}\text { Mahalanobis } \\
\text { distance }\end{array}$ & P value \\
\hline Casino V vs NV & 331.3 & 1.8 & 0.0001 \\
Ambrosetti V vs NV & 196.1 & 1.4 & 0.0001 \\
\hline
\end{tabular}

ment towards the posterior part, a posterior constriction and a slight displacement towards the anterior part in the ligament insertion. In contrast, individuals towards the negative extreme showed a speculate shell shape variation. Individuals located at the positive extreme values of PC2 had a shortening in the umbo area with a slight displacement towards the anterodorsal part and an expansion in the posterior dorsal-ventral area. On the contrary, individuals from the negative extreme showed an elongation of the umbo and a slight displacement towards the ventral area with a shortening in combination of the posterior dorsal-ventral area. Finally, individuals at the positive extreme of PC3 were globe-shaped with ventral widening and a slight contraction in the posterior zone. In contrast, the individuals at the negative extreme were elongated, ventrally compressed and widened in the posterior zone (Fig. 5).

For both rocky salt-marshes, the discriminant analysis showed that shell shape ranges were different between vegetated and non-vegetated patches in a similar way. The mean shell shapes from vegetated patches were significantly different from those from non-vegetated patches (Table 1; Fig. 6). The mean shell shape from the vegetated patches were more dorsoventrally expanded, anterodorsally restricted and globose in shape than those from non-vegetated patches.

\section{DISCUSSION}

In the present field study, we found that the shell shape of the native mussels Perumytilus purpuratus inhabiting Patagonian rocky salt-marshes varies if they grow at vegetated or non-vegetated patches. In these rocky salt-marshes, the presence of vegetation is conspicuous, the native cordgrass Spartina densifloras being the most abundant plant species (Bortolus 2010, Sueiro et al. 2011). The presence of this cordgrass, which is considered a bioengineer organism, modifies the three principal physical factors (temperature, desiccation rate, and wave exposure) that influence the body size and shape of intertidal organisms (Levinton 2001) with respect to adjacent non-vegetated patches (Sueiro et al. 2011). Consequently, mussels growing within vegetation experience different environmental conditions than those growing on non-vegetated patches. Likewise, given the presence on vegetated patches of stems and leaves, which may offer shelter from predators, predation risk may be different from that on nonvegetated patches. Furthermore, mussels within vegetated patches grow in lower densities and form beds several layers thick (a mix of individuals and sediment trapped by the plants), while individuals growing on non-vegetated patches have higher densities and form beds of no more than two thin layers (Sueiro 2012). Thus, several ecological factors differ between the two patch types inhabited by the mussels, and any one or a combination of them could be driving the variation in their shell form. Below we discuss in more detail the main finding of our study.

Mussels sampled from vegetated patches have an ecomorph in which the shells are more dorsoventrally expanded, anterodorsally restricted and globose in shape than those from non-vegetated patches, which showed the opposite traits, resulting in a more elongated shell shape. These findings are in line with those of several studies showing how differences in biotic and abiotic environmental variables can affect the shell form of mussels (Seed 1968, Bergström and Lindergarth 2016, Telesca et al. 2018). For instance, temperature is a critical abiotic factor influencing a number of the biological processes that could drive differences in shell morphology of several mussel species (Peyer et al. 2016, Fitzer et al. 2015).

The mechanisms by which temperature affects shell morphology are not entirely known. However, some authors have proposed that variation could arise from differences in physiological processes that are directly or indirectly involved in shell morphology, such as crystal morphology and growth (Wilbur and Saleuddin 1983), mineralization of shells (Barbariol and Razouls 2000, Stoeckmann 2003, Mestre et al. 2009) and/or water retention (Helmuth 1998). In our study, individuals of $P$. purpuratus exposed to higher temperatures (non-vegetated patches) showed a more elongated shell shape than individuals exposed to lower temperatures (vegetated patches). This result could be related to the notion that elongated shell shapes retain a greater volume of extra-corporeal water than spherical ones, which in turn may ameliorate thermal stress under higher temperatures (Kirby and Bayne 1994). Further, this shell shape may compensate for higher water losses imposed by the higher desiccation rates experienced by individuals from vegetated patches compared with those experienced by individuals from non-vegetated patches. Another abiotic variable known to have a profound effect on mollusc shell shape is wave exposure (Steffani and Branch 2003). For mussels in exposed habitats, where high hydrodynamic forces are imposed, a more compact shell morphology has been reported than those observed in mussels in sheltered habitats (Steffani and Branch 2003). These observations therefore support the find of our study that mussels exposed to higher wave action showed a slenderer shell than mussels within vegetated patches.

Regarding biotic factors, although predation risk has not been measured in the study system, it is worth mentioning that Patagonian rocky shores are considered one of the most physically demanding intertidal habitats (Bertness et al. 2006). Numerous studies have suggested that their communities are overwhelmingly driven by their extreme physical conditions instead of predation effects (Bertness et al. 2006, Hidalgo et al. 2007, Silliman et al. 2011) (i.e. a bottom-up process). Therefore, predation may not play a significant role in shell shape variation in our study system. 
However, numerous studies have demonstrated how predation could play the main role in shell morphology changes, especially in those environments where this biotic pressure is key for structuring communities (Seed 1969, Beadman et al. 2003, Kirk et al. 2007). On the other hand, population density is probably the most significant biotic factor affecting shell shape of $P$. purpuratus. As mentioned, individuals growing in higher densities and forming thin-layer beds (i.e. nonvegetated patches) were elongated in shape. It is likely that population density through physical compression by surrounding individuals could become a restriction to increase in lateral directions, determining that mussels increase in length and tend to be narrower. Conversely, mussels in less crowded conditions (vegetated patches) were not exposed to that type of lateral compression, so they did not develop a shell with a restricted dorsal-ventral shape but rather a globose shape. It is well known that shell form is greatly influenced by population density (Brown et al. 1976, Alunno-Bruscia et al. 2001). These findings agree with those of several studies reporting that high compression leads to an elongate shape, whereas low compression results in more triangular shape in mussels (Seed 1968, 1973, Brown et al. 1976). Analogous situations have been found in oysters (Tanita and Kikuchi 1957, Chinzei et al. 1982), clams (Ohba 1956, Cigarria and Fernandez 1998), tunicates (Paine and Suchanek 1983) and barnacles (Bertness et al. 1998).

Several environmental factors could be driving the differences observed in $P$. purpuratus shell shape, which highlight that the influence of biotic and abiotic environmental variables in shell morphology is complex. The factors affecting the shell shape are probably many and not mutually exclusive. Our results have revealed the striking phenotypic plasticity of shell form of this native species at a fine-grained scale. Shell morphology has functional and fitness consequences that may limit the distribution of molluscs (Levinton 2001). Thus, developmental plasticity of this trait in response to different environmental conditions might facilitate its colonization of new habitats. The plastic response observed in $P$. purpuratus could be one of the explanations for the success of this species in its ecological range expansion (Trovant et al. 2015). In fact, previous studies have hypothesized that the variation pattern of shell shape of this species could be an adaptation to a specific habitat condition at fine-grained spatial scales, which in turn allowed them to expand their geographical distribution (Márquez et al. 2018). Thereby, in the context of geographical distribution, understanding phenotypic plasticity of species is important in order to get a more complete understanding of how species expand their ecological ranges.

\section{ACKNOWLEDGEMENTS}

We thank Yanina L. Idaszkin and Veronica Savoya for their help during field activities. We are particularly grateful to Gabriela Palacios for going through the manuscript and making exhaustive revision of the language, and for supplying useful comments. This contribution was part of the degree thesis of YGG and was partially funded by the ANPCyT PICT-2018-3197 and CONICET PIP $11220150100241 \mathrm{CO}$ (FM). We thank two anonymous reviewers for their valuable comments. This is publication \#132 of the Laboratorio de Reproducción y Biología Integrativa de Invertebrados Marinos (LARBIM).

\section{REFERENCES}

Adami M., Pastorino G., Orensanz J.M. 2013. Phenotypic differentiation of ecologically significant Brachidontes species co-occurring in intertidal mussel beds from the southwestern Atlantic. Malacologia 56: 1-9. https://doi.org/10.4002/040.056.0204

Addison B. 2009. Shell traits of a marine mussel mediate predation selectivity by crabs and sea stars. J. Shellfish Res. 28: 299-303. https://doi.org/10.2983/035.028.0211

Alunno-Bruscia M., Bourget E., Fréchette M. 2001. Shell allometry and length-mass-density relationship for Mytilus edulis in an experimental food-regulated situation. Mar. Ecol. Prog. Ser. 219: $177-188$.

https://doi.org/10.3354/meps 219177

Barbariol V., Razouls S. 2000. Experimental studies on the respiratory metabolism of Mytilus galloprovincialis (Mollusca Bivalvia) from the Mediterranean Sea (Gulf of Lion). Vie Milieu 50: 87-92.

Baythavong B.S. 2011. Linking the Spatial Scale of Environmental Variation and the Evolution of Phenotypic Plasticity: Selection Favors Adaptive Plasticity in Fine-Grained Environments. Amm. Nat. 178: 75-87. https://doi.org/10.1086/660281

Beadman H., Caldow R., Kaiser M., et al. 2003. How to toughen up your mussels: using mussel shell morphological plasticity to reduce predation losses. Mar. Biol. 142: 487-494. https://doi.org/10.1007/s00227-002-0977-4

Bergström P., Lindegarth M. 2016. Environmental influence on mussel (Mytilus edulis) growth - A quantile regression approach. Estuar. Coast. Shelf. Sci. 171: 123-132. https://doi.org/10.1016/j.ecss.2016.01.040

Bertness M.D., Gaines S.D., Yeh S.M. 1998. Making mountains out of barnacles: the dynamics of acorn barnacle hummocking. Ecology 79: 1382-1394.

https://doi.org/10.1890/0012-9658(1998)079[1382:MMOOBT 12.0.CO;2

Bertness M.D., Mullan C., Silliman B.R., et al. 2006. The community structure of western Atlantic Patagonian rocky shores. Ecol. Mon. 76: 429-460. https://doi.org/10.1890/0012-9615(2006)076[0439:TCSOWA] 2.0.CO;2

Bookstein F. 1991. Morphometric Tools for Landmark Data: Geometric and Biology. Cambridge University Press, New York, $435 \mathrm{pp}$. https://doi.org/10.1017/CBO9780511573064

Bourdeau P.E, Butlin R.K, Brönmark C, et al. 2015. What can aquatic gastropods tell us about phenotypic plasticity? A review and meta-analysis. Heredity 115: 312-321. https://doi.org/10.1038/hdy.2015.58

Bortolus A. 2010. Marismas Patagónicas: las últimas de Sudamérica. Ciencia Hoy 19: 10-15.

Briggs J.C., Bowen B.W. 2013. Marine shelf habitat: biogeography and evolution. J. Biogeogr. 40: 1023-1035. https://doi.org/10.1111/jbi.12082

Brönmark C., Lakowitz T., Hollander J. 2011. Predator-Induced Morphological Plasticity Across Local Populations of a Freshwater Snail. PLoS ONE 6: e21773. https://doi.org/10.1371/journal.pone.0021773

Brown R.A., Seed R., O'Connor J. 1976. A comparison of relative growth in Cerastoderma (=Cardium) edule, Modiolus modiolus, and Mytilus edulis (Mollusca: Bivalvia). J. Zool. (Lond). 179: 297-315. https://doi.org/10.1111/j.1469-7998.1976.tb02298.x

Chinzei K., Savazzi E., Seilacher A. 1982. Adaptional strategies of bivalves living as infaunal secondary soft bottom dwellers. Neues. Jahrb. Geol. Paleaontol. Abh. 164: 229-244.

Cigarria J., Fernandez J. 1998. Manila clam (Ruditapes philippinarum) culture in oyster bag: influence of density on survival, 
growth and biometric relationships. J. Mar. Biol. Assoc. UK 78: 551-560.

https://doi.org/10.1017/S0025315400041618

Covich A.P. 2010. Winning the biodiversity arms race among freshwater gastropods: competition and coexistence through shell variability and predator avoidance. Hydrobiologia 653: 191-215.

https://doi.org/10.1007/s10750-010-0354-0

Cubillo A.M., Peteiro L.G., Fernández-Reiriz M.J., et al. 2012. Influence of stocking density on growth of mussels (Mytilus galloprovincialis) in suspended culture. Aquaculture 342: 103-111. https://doi.org/10.1016/j. aquaculture.2012.02.017

DeWitt T.J., Scheiner S.M. 2004. Phenotypic Plasticity: Functional and Conceptual Approaches, Oxford University Press, 272 pp.

Fitzer S.C., Vittert L., Bowman A., et al. 2015. Ocean acidification and temperature increase impact mussel shell shape and thickness: problematic for protection? Ecol. Evol. 5: 4875-4884. https://doi.org/10.1002/ece3.1756

Fox R.J., Donelson J.M., Schunter C., et al. 2019. Beyond buying time: the role of plasticity in phenotypic adaptation to rapid environmental change. Phil. Trans. R. Soc. B 374: 20180174. https://doi.org/10.1098/rstb.2018.0174

Gao S.B., Mo L.D., Zhang L.H., et al. 2018. Phenotypic plasticity vs. local adaptation in quantitative traits differences of Stipa grandis in semi-arid steppe, China. Sci. Rep. 8: 3148. https://doi.org/10.1038/s41598-018-21557-w

Helmuth B.S. 1998. Intertidal mussel microclimates: predicting the body temperature of a sessile invertebrate. Ecol. Mon. 68: 51-74.

https://doi.org/10.1890/0012-9615(1998)068[0051:IMMPTB] 2.0.CO;2

Hidalgo F.J., Silliman B.R., Bazterrica M.C., et al. 2007. Predation on the rocky shores of Patagonia, Argentina. Estuar. Coast. 30: 886-894. https://doi.org/10.1007/BF02841342

Kirby R.R., Bayne B.L. 1994. Phenotypic variation along a cline in allozyme and karyotype frequencies, and its relationship with habitat, in the dog-whelk Nucella lapillus L. Biol J. Linn. Soc. 53: $255-275$. https://doi.org/10.1111/j.1095-8312.1994.tb01012.x

Kirk M., Esler D., Boyd W.S. 2007. Morphology and density of mussels on natural and aquaculture structure habitats: implications for sea duck predators. Mar. Ecol. Prog. Ser. 346: 179-187. https://doi.org/10.3354/meps07046

Klingenberg C.P. 2011. MorphoJ: an integrated software package for geometric morphometrics. Mol. Ecol. Res. 11: 353-357. https://doi.org/10.1111/j.1755-0998.2010.02924.x

Kroeker K.J., Kordas R.L., Crim R., et al. 2013. Impacts of ocean acidification on marine organisms: quantifying sensitivities and interaction with warming. Global Change Biol. 19: 1884-1896. https://doi.org/10.1111/gcb.12179

Levinton J.S. 2001. Marine Biology: Function, Biodiversity, Ecology, Oxford University Press, New York, 515 pp.

Márquez F., Frizzera A.C., Vázquez N. 2017. Environment-specific shell shape variation in the boring mytilid Leiosolenus patagonicus (d'Orbigny, 1842). Mar. Biol. Res. 13: 246-252. https://doi.org/10.1080/17451000.2016.1248848

Márquez F., Adami M., Trovant B., et al. 2018. Allometric differences on the shell shape of two scorched mussel species along the Atlantic South America coast. Evol. Ecol. 32: 43-56. https://doi.org/10.1007/s10682-018-9928-5

McDonald J.H., Seed R., Koehn R.K. 1991. Allozymes and morphometric characters of three species of Mytilus in the Northern and Southern Hemispheres. Mar. Biol. 111: 323-333. https://doi.org/10.1007/BF01319403

Melatunan S., Calosi P., Rundle S.D., et al. 2013. Effects of ocean acidification and elevated temperature on shell plasticity and its energetic basis in an intertidal gastropod. Mar. Ecol. Prog. Ser. 472: $155-168$ https://doi.org/10.3354/meps 10046

Mestre N.C., Thatje S., Tyler P.A. 2009. The ocean is not deep enough: pressure tolerances during early ontogeny of the blue mussel Mytilus edulis. Proc. R. Soc. Lond. B. Biol. Sci. 276: 717-726. https://doi.org/10.1098/rspb.2008.1376

Miner B.G., Sultan S.E., Morgan S.G., et al. 2005. Ecological consequences of phenotypic plasticity. Trends Ecol. Evol. 20: 685-692.

https://doi.org/10.1016/j.tree.2005.08.002

Mitteroecker P., Gunz P. 2009. Advances in Geometric morphomet- rics. Evol. Biol. 36: 235-247.

https://doi.org/10.1007/s11692-009-9055-x

Monteiro L. 1999. Multivariate regression models and geometric morphometrics: The search for causal factors in the analysis of shape. Syst. Biol. 48: 192-199.

https://doi.org/10.1080/106351599260526

Ohba S. 1956. Effects of population density on mortality and growth in an experimental culture of bivalve, Venerupis semidecussata. Biol. J. Okayama. Univ. 2: 169-173.

Orr J.C., Fabry V.J., Aumont O., et al. 2005. Anthropogenic ocean acidification over the twenty-first century and its impact on calcifying organisms. Nature 437: 681-686. https://doi.org/10.1038/nature04095

Padilla D.K., Savedo M.M. 2013. A systematic review of phenotypic plasticity in marine invertebrate and plant systems. Adv. Mar. Biol. 65: 67-94 https://doi.org/10.1016/B978-0-12-410498-3.00002-1

Paine R.T., Suchanek T.H. 1983. Convergence of ecological processes between independently evolved competitive dominants: a tunicate-mussel comparison. Evolution 37: 821-831. https://doi.org/10.1111/j.1558-5646.1983.tb05603.x

Peyer S.M., Hermanson J.C., Lee C.E. 2016. Developmental plasticity of shell morphology of quagga mussels from shallow and deep-water habitats of the Great Lakes. J. Exp. Biol. 213: 2602-2609. https://doi.org/10.1242/jeb.042549

Piersma T., Van Gils J.A. 2011. The flexible phenotype: a bodycentred integration of ecology, physiology, and behaviour. Oxford University Press, New York, 222 pp.

Rohlf F.J. 2004. TPS Shareware Series. Department of Ecology and Evolution, State University of New York, Stony Brook, New York.

Rohlf F.J. 2016a. TpsUtil. version 1.70. Department of Ecology and Evolution, State University of New York Stony Brook, New York.

Rohlf F.J. 2016b. TpsRelw. version 1.64. Department of Ecology and Evolution, State University of New York Stony Brook, NY New York.

Rohlf F.J., Slice D. 1990. Extensions of the Procrustes Method for the Optimal Superimposition of Landmarks. Syst. Biol. 39: 40-59. https://doi.org/10.2307/2992207

Scheiner S.M.1993. Genetics and evolution of phenotypic plasticity. Annu. Rev. Ecol. Syst. 24: 35-68 https://doi.org/10.1146/annurev.es.24.110193.000343

Scherer A.E., Lunt J., Draper A.M., et al. 2016. Phenotypic plasticity in oysters (Crassostrea virginica) mediated by chemical signals from predators and injured prey. Invert. Biol. 135: 97-107. https://doi.org/10.1111/ivb.12120

Schwenk K., Padilla D.K., Bakken G.S., et al. 2009. Grand challenges in organismal biology. Integr. Comp. Biol. 49: 7-14. https://doi.org/10.1093/icb/icp034

Seed R. 1968. Factors influencing shell shape in Mytilus edulis. J. Mar. Biol. Assoc. UK 48: 561-584. https://doi.org/10.1017/S0025315400019159

Seed R. 1969. The ecology of Mytilus edulis L. (Lamellibranchiata) on exposed rocky shores. II. Growth and mortality. Oecologia 3: 317-335 https://doi.org/10.1007/BF00390381

Seed R. 1973. Absolute and allometric growth in the mussel, Mytilus edulis L. (Mollusca Bivalvia). Proc. Malacol. Soc. Lond. 40: 343-357.

Silliman B.R., Bertness M.D., Altieri A.H., et al. 2011. Wholecommunity facilitation regulates biodiversity on Patagonian rocky shores. PloS ONE 6: e24502. https://doi.org/10.1371/journal.pone.0024502

Soot-Ryen T. 1955. A report on the family Mytilidae (Pelecypoda). Allan Hancock Pacific Expeditions (series) 20. Univ. South California, Los Angeles. 174 pp.

Steffani C.N., Branch G.M. 2003. Growth rate, condition, and shell shape of Mytilus galloprovincialis: responses to wave exposure. Mar. Ecol. Prog. Ser. 246: 197-209. https://doi.org/10.3354/meps246197

Stoeckmann A. 2003. Physiological energetics of Lake Erie dreissenid mussels: a basis for the displacement of Dreissena polymorpha by Dreissena bugensis. Can. J.Fish. Aquat. Sci. 60: 126-134. https://doi.org/10.1139/f03-005

Sueiro M.C. 2012. Plantas vasculares como agentes modificadores de ecosistemas en la costa Patagónica. Universidad de Buenos 
Aires, $\mathrm{PhD}$ thesis $131 \mathrm{pp}$.

Sueiro M.C., Bortolus A., Schwindt E. 2011. Habitat complexity and community composition: relationships between different ecosystem engineers and the associated macroinvertebrate assemblages. Helgol. Mar. Res. 65: 467-477. https://doi.org/10.1007/s10152-010-0236-X

Sueiro M.C., Bortolus A., Schwindt E. 2012. The role of the physical structure of Spartina densiflora Brong. in structuring macroinvertebrate assemblages. Aquatic. Ecol. 46: 25-36. https://doi.org/10.1007/s10452-011-9379-3

Tanita S., Kikuchi S. 1957. On the density effect of the raft cultured oysters. I. The density effect within one plate. Bull. Tohoku. Reg. Fish. Lab. Res. 9: 133-142.

Telesca L., Michalek K., Sanders T., et al. 2018. Blue mussel shell shape plasticity and natural environments: a quantitative approach. Sci. Rep. 8: 2865.

https://doi.org/10.1038/s41598-018-20122-9
Trivellini M.M., Van der Molen S., Márquez F. 2018. Fluctuating asymmetry in the shell shape of the Atlantic Patagonian mussel, Mytilus platensis, generated by habitat-specific constraints. Hydrobiologia 822: 189-201. https://doi.org/10.1007/s10750-018-3679-8

Trovant B., Orensanz J.M., Ruzzante D.E., et al. 2015. Scorched mussels (Bivalvia: Mytilidae: Brachidontinae) from the temperate coasts of South America: Phylogenetic relationships, trans-Pacific connections and the footprints of Quaternary glaciations. Mol. Phylogenetics. Evol. 82: 60-74. https://doi.org/10.1016/j.ympev.2014.10.002

Wilbur K.M. Saleuddin A.S.M. 1983. Shell formation. In: Wilbur K.M., Saleuddin A.S.M. (eds), The Mollusca, Academic Press, New York, pp. 235-287. https://doi.org/10.1016/B978-0-12-751404-8.50014-1

Zelditch M.L., Swiderski D.L., Sheets H.D., et al. 2004. Geometric Morphometrics for Biologists. Ed. Elsevier, London, 443 pp. 